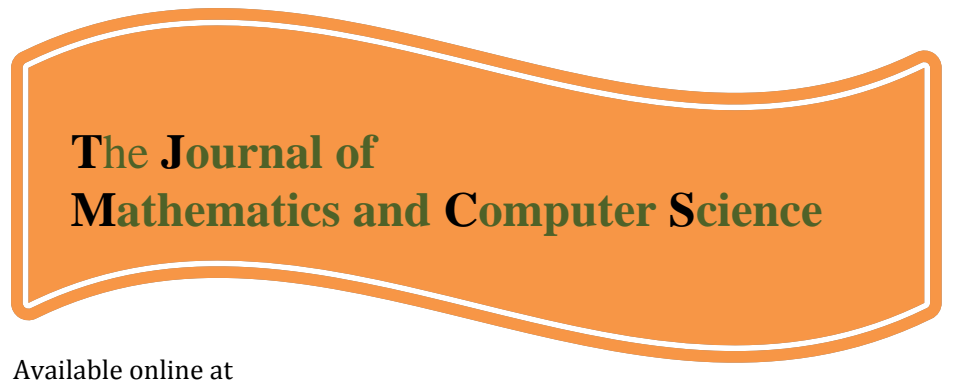

http://www.TJMCS.com

The Journal of Mathematics and Computer Science Vol .2 No.3 (2011) 459-468

\title{
Application of Fuzzy Optimization in Diet Formulation
}

\author{
D. Darvishi SalooKolayi ${ }^{1,}{ }^{*}$, A. Teimouri Yansari ${ }^{2}$, S. h. Nasseri ${ }^{3}$ \\ Drvishidavood@yahoo.com \\ a.teimouri@umz.ac.ir \\ nasseri@umz.ac.ir
}

Received: August 2010, Revised: November 2010

Online Publication: January 2011

\begin{abstract}
Feeding cost comprised about 65 to 75 percentage of dairy cattle production systems. Reduction feed cost and consideration seasonal or regional limitation of feed sources especially some forages increased necessity of the optimization of feed formulation in dairy caws. However, without a positive answer and accrue methods based on linear models those used on ration formulation, application of new mathematical models as fuzzy models seems to be very useful to taken account and meeting nutrient requirements and formulation based on ration least cost and composition in different levels. Fuzzy models promise to be a valuable tool as they link measurable information to linguistic interpretation using membership functions. The objective of this paper was using linear fuzzy model in formulation of dairy cow ration in early lactation and compare to linear programming models. Using linear programming models, the final cost of one kilogram of total mixed ration was 1333.5 Rails, and at this level cow nutrients requirements were met. Using fuzzy model and applying all restriction, the least cost for one kilogram of total mixed ration was 1222.5 Rails, and at this level cow nutrients requirements were met. Using fuzzy model in compare to linear programming models, feed cost was reduced about 8 percentages. The result of this experiment guarantees the formulation of ration using fuzzy models can be used to reduce feed cost and obtain different ration that they may met dairy cow nutrients requirements over different situations. In addition, because of the results in an
\end{abstract}

\footnotetext{
1,* Department of Mathematics, Payeme Noor University, Bandpey branch,Babol, Iran.

2 Department of Animal Science, University of Agriculture and Bioresource of Sari, Sari, Mazandaran, Iran

3 Department of Mathematics and Computer Sciences, Mazandaran University, Babolsar, Iran.
} 
illustrative example, it is concluded that the procedure outlined in this paper suitably deals with ration formulation and, therefore, enables a practical implementation of fuzzy evaluation of agricultural production systems.

Keywords: ration formulation, linear fuzzy model, dairy cow.

\section{Introduction}

Feeding cost comprised about 65 to 75 percentage of dairy cattle production systems. Reduction feed cost and consideration seasonal or regional limitation of feed sources especially some forages increased necessity of the optimization of feed formulation in dairy cows. One of the real opportunities in controlling costs in dairy cattle industries is carefully planning feed requirements to maximize milk production. When formulating a ration, the goal is to provide the animal with the proper quantity of feed that will supply the necessary nutrients at a low cost. To reduce the cost of feeding, a least-cost ration formulation could be used. However, the nutrient requirements of dairy cows differ as they progress through various stages of lactation, and gestation (NRC, 1989). To account for these differences makes calculating a least-cost ration more complex. One method that can be used to derive least-cost rations is linear programming (LP), which assumes first, that all inputs into the ration are infinitely divisible; and, second, their nutrient content is known (Roush et al., 1996; St. Pierre and Harvey, 1986). The first assumption is valid in ration formulation, as it is possible to use as much or as little of an ingredient as desired. The most recent criticisms against the applicability of LP in this field primarily lie in two points. First, the reliance on the cost of blend as the only relevant criterion for decision maker. Second, the very rigid character of the nutritional requirements.

A difficulty that arises in formulating dairy cattle rations is that they are usually fed a diet made up principally of forages, such as hay and silage, within which the nutrient content of the diet can vary widely. The variation in nutrient content could have a negative impact on the production of the animals, particularly if a producer considers the ration has sufficient nutrient content based on mean values. As a result, the variation in nutrients should be considered when formulating the ration for each stage of lactation period. The second assumption of LP may be invalid in most cases, as variation does exist in many feed nutrients.

Several methods can be used to reduce the effects of variability in nutrient content in ration formulation. One of these methods is to incorporate a safety margin into the ration formulation; another is to increase the concentrations of the nutrient in the ration formulation. These methods are referred to as the safety margin (SM) formulation and the right-hand side adjustment (RS) model (Roush et al., 1996; St. Pierre and Harvey, 1986). Another potential method is lead feeding, which accounts for variability in the requirements of a group of animals, such as milking cow groups-for which production varies throughout the group due to different stages of lactation and body weight-by calculating a factor that is based on the variability of production (Stallings and McGilliard, 1984). The nutrient requirements of the group are then multiplied by this factor; hence, lead feeding is similar to a combination of the SM and RS formulations. Another method is stochastic programming (SP), which explicitly accounts for variation in the ration ingredients through the 
mathematical structure of the problem. The method in which nutrient variability is incorporated into a formulated ration affects the cost of the ration and the ingredient content of the ration. Stochastic programming minimized the ration cost and level of overfeeding of CP compared with adjusting the nutrient level through an SM or RS adjustment (Tozer, 2000).

When no variability in the nutrient content of the ingredients of a ration is assumed, the typical method of formulation is to use the mean value for the nutrient in question. When variability does exist, it is possible to determine the probability that the nutrient meets or exceeds the requirements specified in the ration. By ignoring variability, the probability that the nutrient concentration in the ration exceeds the desired level is only $50 \%$, assuming a normally distributed nutrient content (Roush et al., 1996). With other formulations, such as SM or SP, the probability of exceeding the desired level can be increased beyond 50\%. The mean values for an individual farm can be determined by forage or feed analysis, or the farmer may choose to use book values, such as those presented in the NRC Nutrient Requirements for Dairy Cattle (NRC, 2001). However, neither of these sources provides information regarding the variation of nutrient content in these feeds.

However, without a positive answer and accrue methods based on linear models those used on ration formulation, application of new mathematical models as fuzzy models seems to be very useful to taken account and meeting nutrient requirements and formulation based on ration least cost and composition in different levels. Fuzzy models promise to be a valuable tool as they link measurable information to linguistic interpretation using membership functions. The objective of this paper was using linear fuzzy model in formulation of dairy cow ration in early lactation and compare to linear programming models. Using fuzzy logic by analyzing, Ido et al., (2001) indicated that using fuzzy logic was that it enabled improved concentrate feeding ration according to performance. The system enabled to automate decision making, thus providing the farmer with a valuable tool. However, from an economic point of view no significant statistical improvement was achieved by the fuzzy logic system. This study derive a least-cost feed ration for dairy cattle at early lactation by the fuzzy model that mentioned as methods above and by incorporating ration ingredients that are readily available in the northeast of the Iran.

\section{Materials and Methods}

Some Iranian feedstuffs including alfalfa hay, barley, wheat bran, sugar beet pulp, corn silage, cottonseed meal, sugar beet molasses, supplemental fat and minerals were used to formulation of a ration for early lactating Holstein dairy cows. Chemical compositions of feeds are presented in Table 1. Diets were formulated using the national research council system (NRC, 2001) to supply adequate NEL and protein for a 600 to $700 \mathrm{~kg}$ cow producing $30 \mathrm{~kg} / \mathrm{d}$ of milk, with $3.2 \%$ fat and 3.5\% CP. The maximum and minimal requirements of dairy cows as consistent and fuzzy were extracted from the national research council system (NRC, 2001; Table 2). Using fuzzy constant on QSB software the formulation of ration was conducted.

A linear programming problem covers, on objective function and a series of constraints. Usually the objective function classification with $\mathrm{n}$ function $Z\left(x_{1}, x_{2}, \ldots, x_{n}\right)$ that the optimum amount of classification is asset of constraints which is defined by the given limitation with the function of 
$i=1, \ldots, m, g_{i}=\left(x_{1}, x_{2}, \ldots, x_{n}\right) \geq(\leq) b_{i}$ were determined Consider the following fuzzy linear programming:

$$
\operatorname{Min} \sum_{j=1}^{n} c_{j} x_{j}
$$

s.t. $\quad k_{i} \leq \sum_{j=1}^{n} a_{i j} x_{j} \leq p_{i}, \quad, i=1, \ldots, m$

$m_{j} \leq x_{j} \leq M_{j}, \quad \cdot j=1, \ldots, n$

The first equation of objective function, is making the minimum of fixed cost of fully mixed diet; c, are the current cost of food; $x$, is the amount of food. Equations of 2 and 3 are the limitation of the nutrients and food consumption, respectively. Also each of the numerical coefficients can be expressed as fuzzy number with regard to conditions considered being the problem. The goal of this programming is providing of a minimum supply of nutrients by taking a sense of animal with combined oral specific nutrients which they use to achieve maximum milk production is in livestock. In this case, using symmetric fuzzy linear programming needs to be considered as fuzzy numbers. In this modeling assume that the person does not decide to maximum or minimum the objective function but also intends to phase it reaches the desired level or the constraints are fulfilled in a satisfactory in this way, the difference between objective function and constraints are diminished and the original objective function as a limitation into the model is in fact will be a kind of symmetry between objective and limitations. Insider the following notwithstanding the larger equal fuzzy:

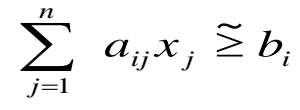

That, bi is like fuzzy numbers with ti (>0).now, if we defined the inequality (4) as follow, then we will have: $\sum_{j=1}^{n} a_{i j} x_{j} \geq\left(b_{i}-t_{i}, b_{i}\right)$

If we show the satisfaction of this constraints whit , then membership function chart will be in the form of figure1.

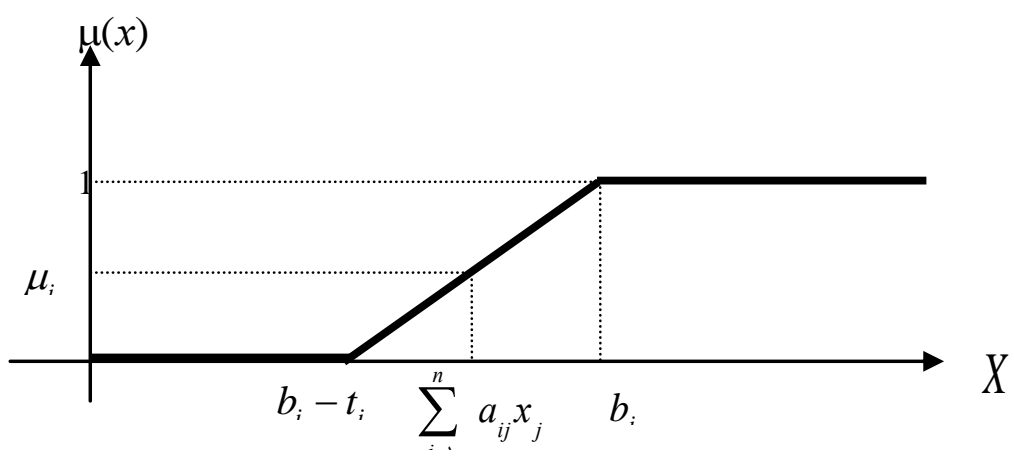

Figure1: membership function(the amount of satisfaction)the larger limitation of equal fuzzy. 
That bi-ti are the starting point of limitation of $i$ and ti is the deviation of this permissible restriction $\sum_{j=1}^{n} a_{i j} x_{j}$ is about the $\mathrm{i}$ limitation as can be seen in figure 1 , if the restrict in $\sum_{j=1}^{n} a_{i j} x_{j}$ is greater than bi , the amount of satisfaction and equal one and also the smaller amount than bi-ti ,will be zero. Between these value, the amount of satisfaction also will be between zero and one.(with this assumption that we wants to maximize the $\lambda_{i}$

$\lambda_{i}=\left[\sum_{j=1}^{n} a_{i j} x_{j}-\left(b_{i}-t_{i}\right)\right] / t_{i}$

So we will have:

$$
\mu_{i}=\left\{\begin{array}{lc}
1 & : b_{i} \leq \sum_{j=1}^{n} a_{i j} x_{j} \\
{\left[\sum_{j=1}^{n} a_{i j} x_{j}-\left(b_{i}-t_{i}\right)\right] / t_{i}} & :\left(b_{i}-t_{i}\right) \leq \sum_{j=1}^{n} a_{i j} x_{j} \leq b_{i} \\
0 & : \sum_{j=1}^{n} a_{i j} x_{j} \leq b_{i}-\mathrm{t}_{\mathrm{i}}
\end{array}\right.
$$

By multiplying of it on each side with equation (6), we will have $\sum_{j=1}^{n} a_{i j} x_{j}-t_{i} \lambda_{i} \geq b_{i}-t_{i}$ :

And similarly for smaller constraint equal phase we will also have: $\sum_{j=1}^{n} a_{i j} x_{j}+t_{i} \lambda_{i} \leq b_{i}+t_{i}$

Now if we put $\lambda$ equal to minimum $\lambda_{i}$, linear programming will be as follows:

\section{$\operatorname{Max} \lambda$}

s.t. $\quad \sum_{j=1}^{n} a_{i j} x_{j}-\mathrm{t}_{i} \lambda \geq b_{i}-t_{i}$

$\sum_{j=1}^{n} a_{i j} x_{j}+\mathrm{t}_{i} \lambda \leq b_{i}+t_{i}$

$\lambda \leq 1$

$\lambda, x_{j} \geq 0$

Determined in formula(8), our goal here is maximizing the minimum constraints the amounts that accept $\lambda$, is between one and zero that should be added to model as a limitation. The best case is $\lambda$ much more to be closer. Therefore, the amount of satisfaction considered as fuzzy test. In this 
study, linear programming, fuzz symmetric have been used for setting of fully mixed diet of lactating cows in early lactation(from the time of calving until 70 days after delivery that weight between 600 to700 kg. and the results have been compared with the results of ordinary linear model programming.

\section{Results and Discussion}

The result of constant model and linear fuzzy model were presented in Table 3 . The least cost of ration that may meet total nutrient requirements of dairy cow was 1335.7 Rail per kilogram of a total mixed ration. This ration has consistent limitation that has solved with linear programming method. However, the composition based inference function works for single-input/single-output systems. To use the composition based inference function, a fuzzy relation must be created which models a system's input-output response. The fuzzy inference function then takes a fuzzy set as input and performs a composition to arrive at the output. What follows is a description of what is needed to perform a composition based inference and a demonstration of the differencing operation. However, using fuzzy model with extensive limitation, there were collection of responses. All of these rations are fine and meet animal requirements when their price is calculated, but based on herd condition, feed availability, and cost, we can choose suitable ration.

Applying fuzzy model with restrictions to coast of model, we considered $\lambda=0$ and $\lambda=1$ achieved to minimize cost and eliminated cost limitation from the model. Based on cost coasts in model, ration least cost that achieved when $\lambda=0$ and $\lambda=1$ were 1476.9 and $1222.5 \mathrm{Rial} / \mathrm{kg}$ (Table 3).

Table 1. Chemical compositions of feeds

\begin{tabular}{lcccccccc}
\hline Feeds & $\begin{array}{c}\text { NEl } \\
(\mathrm{Kcal} / \mathrm{kg})\end{array}$ & $\begin{array}{c}\text { Crud protein } \\
(\mathrm{g} / \mathrm{kg})\end{array}$ & $\begin{array}{c}\text { Fat } \\
(\mathrm{g} / \mathrm{kg})\end{array}$ & $\begin{array}{c}\mathrm{NDF}^{1} \\
(\mathrm{~g} / \mathrm{kg})\end{array}$ & $\begin{array}{c}\mathrm{NFC}^{2} \\
(\mathrm{~g} / \mathrm{kg})\end{array}$ & $\begin{array}{c}\mathrm{Ca} \\
(\mathrm{g} / \mathrm{kg})\end{array}$ & $\begin{array}{c}\mathrm{P} \\
(\mathrm{g} / \mathrm{kg})\end{array}$ & $\begin{array}{c}\text { Price } \\
(\mathrm{Rial} / \mathrm{kg})^{3}\end{array}$ \\
\hline Alfalfa & 1190 & 192 & 25 & 416 & 257 & 14.7 & 2.8 & 1750 \\
Barely grain & 1860 & 124 & 22 & 208 & 617 & 0.6 & 3.9 & 1700 \\
Sugar beet pulp & 1470 & 10 & 11 & 458 & 358 & 9.1 & 0.9 & 1900 \\
Corn silage & 1450 & 88 & 32 & 450 & 387 & 2.8 & 2.6 & 700 \\
Cottonseed meal & 1710 & 449 & 19 & 308 & 157 & 2 & 11.5 & 2150 \\
Fat supplement & 5020 & 0 & 845 & 0 & 0 & 120 & 0 & 2500 \\
Sugar beet molasses & 1840 & 85 & 2 & 1 & 798 & 1.5 & 0.3 & 700 \\
Soybean meal & 2130 & 499 & 16 & 149 & 270 & 4 & 7.1 & 3200 \\
Sunflower meal & 1380 & 284 & 14 & 403 & 222 & 4.8 & 10 & 1200 \\
Wheat bran & 1610 & 173 & 43 & 425 & 296 & 1.3 & 11.8 & 750 \\
Oyster meal & & & & & & 380 & & 250 \\
\hline
\end{tabular}

1-Neutral Detergent Fiber (NDF)

2- Non Fibrous Carbohydrates (NFC)

3- The feed price obtained from Mazandran Farming and Animal Husbandry Cooperative Union at October 2005.

Table 2. The nutrient requirements and their limitation in Holstein dairy cows with body weight 600 to $700 \mathrm{~kg}$ as consistent and fuzzy were extracted from the national research council system (NRC, 2001).

\begin{tabular}{|c|c|c|c|c|c|c|c|c|c|}
\hline \multirow{3}{*}{$\begin{array}{l}\text { Nutrient requirements } \\
\text { Energy }\end{array}$} & \multirow{3}{*}{$\begin{array}{c}\text { Unit } \\
\text { Kcal/kg }\end{array}$} & \multicolumn{3}{|c|}{ Consistent model } & \multicolumn{5}{|c|}{ Fuzzy model } \\
\hline & & \multirow{2}{*}{$\begin{array}{c}\text { Minimum } \\
1500\end{array}$} & \multirow{2}{*}{$\begin{array}{c}\text { Maximum } \\
1650\end{array}$} & \multirow[t]{2}{*}{ Equivalent } & \multicolumn{2}{|c|}{ Minimum } & \multicolumn{2}{|c|}{ Maximum } & Equivalent \\
\hline & & & & & 1520 & 1480 & 1700 & 1600 & \\
\hline Protein & Gram & 155 & 180 & & 160 & 150 & 190 & 170 & \\
\hline
\end{tabular}


D. Darvishi SalooKolayi, A. Teimouri Yansari, S. h. Nasseri/ TJMCS Vol .2 No.3 (2011) 459-468

\begin{tabular}{|c|c|c|c|c|c|c|c|c|c|c|}
\hline Ether extract & Gram & 30 & 80 & & 35 & 25 & 90 & 70 & & \\
\hline Neutral detergent fiber & Gram & 300 & 400 & & 320 & 280 & 420 & 380 & & \\
\hline $\begin{array}{l}\text { Non Fibrous } \\
\text { carbohydrate }\end{array}$ & Gram & 350 & 420 & & 380 & 320 & 440 & 400 & & \\
\hline Calcium (Ca) & Gram & 10 & & & 10.5 & 9.5 & & & & \\
\hline Phosphor (P) & Gram & 5 & & & 5.25 & 4.75 & & & & \\
\hline $\begin{array}{l}\text { Amount of } \\
\text { carbohydrate }\end{array}$ & Gram & & 730 & & & & 740 & 720 & & \\
\hline Ratio of Ca: P & Gram & & & 2 & & & & & 2.1 & 1.9 \\
\hline Total ration & Gram & & & 1 & & & & & & 1 \\
\hline Alfalfa hay & Gram & & 250 & & & & 280 & 220 & & \\
\hline Barely grain & Gram & & 300 & & & & 320 & 280 & & \\
\hline Sugar beet pulp & Gram & & 150 & & & & 200 & 100 & & \\
\hline Corn silage & Gram & & 150 & & & & 200 & 100 & & \\
\hline Cottonseed meal & Gram & & 120 & & & & 140 & 100 & & \\
\hline Fat supplement & Gram & & 40 & & & & 50 & 30 & & \\
\hline Sugar beet molasses & Gram & & 30 & & & & 35 & 25 & & \\
\hline Soybean meal & Gram & & 120 & & & & 140 & 100 & & \\
\hline Sunflower meal & Gram & & 100 & & & & 120 & 80 & & \\
\hline Wheat bran & Gram & & 150 & & & & 170 & 125 & & \\
\hline Oyster meal & Gram & & 25 & & & & 30 & 20 & & \\
\hline
\end{tabular}

Table 3. The rations obtained as consistent and fuzzy model responses.

\begin{tabular}{|c|c|c|c|c|c|c|c|c|c|}
\hline \multirow[b]{2}{*}{ Ration } & \multirow{3}{*}{$\begin{array}{c}\text { Consiste } \\
\text { nt model } \\
\text { A }\end{array}$} & \multicolumn{2}{|c|}{$\begin{array}{l}\text { Low and high limit of } \\
\text { fuzzy model } \\
\text { response }\end{array}$} & \multicolumn{6}{|c|}{ Responses of fuzzy model } \\
\hline & & B & $\mathrm{C}$ & $\mathrm{D}$ & E & $\mathrm{F}$ & G & $\mathrm{H}$ & $\mathrm{I}$ \\
\hline Feed ingredients & & Min & Max & $1222<$ tsoc $<1477$ & $1222<$ tsoc $<1307$ & $1307<$ tsoc $<1392$ & $1392<$ tsoc $<1477$ & $1222<$ tsoc $<1349.5$ & $1349.5<$ tsoc $<1477$ \\
\hline Alfalfa hay(gr) & 250 & 194.3 & 185.4 & 225.5 & 204.9 & 226.1 & 201.9 & 222.9 & 229.2 \\
\hline Barely grain(gr) & 280.8 & 257.8 & 280 & 288.7 & 306.7 & 298.1 & 289.4 & 304.6 & 292.1 \\
\hline Sugar beet pulp(gr) & & & 90.3 & & & & 22.6 & & \\
\hline Corn silage(gr) & 150 & 200 & 100 & 146.7 & 169.8 & 145.3 & 123.6 & 161.4 & 130.2 \\
\hline Cottonseed meal(gr) & 21.5 & & 88.3 & 30.9 & & 34 & 83.7 & 1.1 & 6.8 \\
\hline Fat supplement(gr) & 5.3 & & 14 & 5.9 & 2.7 & 6.1 & 9.8 & 3.8 & 8.3 \\
\hline Sugar beet molasses(gr) & 30 & 35 & 25 & 29.7 & 32 & 29.5 & 27.4 & 31.1 & 28 \\
\hline Soybean meal(gr) & & & & & & & & & \\
\hline Sunflower meal(gr) & 100 & 120 & 80 & 98.7 & 107.9 & 98.1 & 89.4 & 104.6 & 92.1 \\
\hline Wheat bran(gr) & 150 & 175 & 125 & 148.4 & 159.9 & 147.7 & 136.8 & 155.7 & 140.1 \\
\hline Oyster meal(gr) & 12.5 & 17.9 & 12 & 15 & 16.1 & 15 & 15.5 & 14.9 & 15.1 \\
\hline $\begin{array}{l}\text { Meet the minimum } \\
\text { degree of fuzzy } \\
\text { constraints(\%) }\end{array}$ & & 0 & 100 & 53.19 & 30.19 & 54.68 & 76.45 & 38.60 & 69.78 \\
\hline
\end{tabular}


Table 4. The amount of requirement that met through the different rations that that obtained as consistent and fuzzy model responses.

\begin{tabular}{|c|c|c|c|c|c|c|c|c|c|}
\hline \multirow{2}{*}{$\begin{array}{l}\text { The amount of } \\
\text { requirement that met }\end{array}$} & \multirow{2}{*}{$\begin{array}{c}\text { Consistent } \\
\text { model } \\
\text { A }\end{array}$} & \multicolumn{8}{|c|}{ Fuzzy model } \\
\hline & & B & C & D & $\mathbf{E}$ & $\mathbf{F}$ & $\mathbf{G}$ & $\mathbf{H}$ & I \\
\hline NEl (Kcal/kg) & 1535.03 & 1512.5 & 1597.79 & 1549.38 & 1539.28 & 1550.43 & 1577.35 & 1539.04 & 1561.5 \\
\hline Protein (gram) & 162.55 & 154.2 & 166.12 & 163.41 & 153.34 & 164.35 & 174.71 & 154.55 & 173.55 \\
\hline Ether extract (gram) & 30 & 26.2 & 35 & 30.31 & 28.04 & 30.44 & 32.68 & 28.89 & 31.94 \\
\hline $\begin{array}{l}\text { Neutral detergent fiber } \\
\text { (gram) }\end{array}$ & 340.58 & 347.22 & 344.29 & 334.52 & 336.92 & 334.26 & 330.13 & 337.41 & 331.34 \\
\hline $\begin{array}{l}\text { Non Fibrous } \\
\text { carbohydrate (gram) }\end{array}$ & 389.42 & 392.77 & 380 & 393.53 & 403.43 & 392.64 & 373.72 & 401.98 & 383.95 \\
\hline Calcium (Ca) (gram) & 10.42 & 11.22 & 11.02 & 12.02 & 11.12 & 11.12 & 11.09 & 11.11 & 11.44 \\
\hline Phosphor (P) (gram) & 5.21 & 5.34 & 5.25 & 5.03 & 5.19 & 5.3 & 4.55 & 5.14 & 5.45 \\
\hline Price (Rial/kg) & 1335.71 & 1222.52 & 1476.93 & 1341.06 & 1281.41 & 1345.4 & 1412.15 & 1300.53 & 1387.85 \\
\hline
\end{tabular}

Table 5. The comparison of different diet based on both nutrient requirements and cost.

\begin{tabular}{|c|c|c|c|c|c|c|c|c|c|}
\hline NEl (Kcal/kg) & B & A & $\mathrm{H}$ & $\mathrm{E}$ & $\mathrm{D}$ & $\mathrm{F}$ & I & G & $\mathrm{C}$ \\
\hline Protein (gram) & $\mathrm{E}$ & B & $\mathrm{H}$ & A & $\mathrm{D}$ & $\mathrm{F}$ & $\mathrm{C}$ & I & G \\
\hline Ether extract (gram) & B & $\mathrm{E}$ & $\mathrm{H}$ & A & $\mathrm{D}$ & $\mathrm{F}$ & I & G & $\mathrm{C}$ \\
\hline $\begin{array}{l}\text { Neutral detergent fiber } \\
\text { (gram) }\end{array}$ & G & I & $\mathrm{F}$ & $\mathrm{C}$ & $\mathrm{D}$ & $\mathrm{E}$ & $\mathrm{H}$ & A & B \\
\hline $\begin{array}{l}\text { Non Fibrous carbohydrate } \\
\text { (gram) }\end{array}$ & G & $\mathrm{C}$ & I & A & $\mathrm{F}$ & B & $\mathrm{D}$ & $\mathrm{H}$ & $\mathrm{E}$ \\
\hline Calcium (Ca) (gram) & A & $\mathrm{C}$ & G & $\mathrm{H}$ & $\mathrm{E}, \mathrm{F}$ & B & I & $\mathrm{D}$ & \\
\hline Phosphor (P) (gram) & G & $\mathrm{D}$ & $\mathrm{H}$ & $\mathrm{E}$ & A & $\mathrm{C}$ & $\mathrm{F}$ & B & I \\
\hline Cost(rial) & B & $\mathrm{E}$ & $\mathrm{H}$ & A & $\mathrm{D}$ & $\mathrm{F}$ & I & G & $\mathrm{C}$ \\
\hline
\end{tabular}

The potential to introduce the variance of response and the variation of the feeds being fed has been realized. The use of fuzzy model approaches allows nutritionists and dairy producers to manage better a heterogeneous population of cows in a herd via formulating the ration. In addition, nutrition programs will be more mechanistically based, thus permitting a more robust application of scientific knowledge. Information flow from basic and applied research to application models needs to become more efficient. Some research has been redundant and poorly defined, and the experimental designs have not always permitted questions about the biological response to an 
input. The use of the modeling tools is now changing these conditions. It seems that the results that obtained to apply fuzzy model must be use in the designs of future experiments.

\section{References}

1. D'Alfonso, T. H., W. B. Roush, and J. A. Ventura. 1992. Least cost poultry rations with nutrient variability: a comparison of linear programming with a margin of safety and stochastic programming models. Poult. Sci. 255-262.

2. National Research Council (NRC). 2001. Nutrient Requirements of Dairy Cattle. 7th rev. ed. Natl. Acad. Sci., Washington, DC.

3. Roush, W. B., T. L. Cravener, and F. Zhang. 1996. Computer formulation observations and caveats. J. Appl. Poultry. Res. 5:116-125.

4. St. Pierre, N. R., and W. R. Harvey. 1986. Incorporation of uncertainty in composition of feeds into least-cost ration models. 1. Single-chance constrained programming. J. Dairy Sci. 69:3051- 3062.

5. Sniffen, C. J., R. W. Beverly, C. S. Mooney, M. B. Roe, A. L. Skidmore, and J. R. Black. 1993. Nutrient requirements versus supply in the dairy cow: strategies to account for variability. J. Dairy Sci. 76:3160-3178.

6. Stallings, C. C., and M. L. McGilliard. 1984. Lead factors for total mixed ration formulation. J. Dairy Sci. 67:902-907.

7. Tozer, P.R. 2000. Least-cost ration formulations for Holstein dairy heifers by using linear and stochastic programming. J. Dairy Sci 83:443-451.

8. Owen-Smith, Norman (1993) Assessing the constraints for optimal diet models. Evolutionary Ecology (5)

9. Ido, M., Y. Edan and E. Maltz. 2001. IT-information technology: an individual feed allocation decision support system for the dairy farm. J. of Agricultural Engineering Research.79:2:167-176.

10. Belman, R.E. and Zadeh, L.A. (1970). Decision making in a fuzzy environment. Management Science. 17: 141-164.

11. Cadenas, J.M., Pelta, D.A., Pelta, H.R. and Verdegay, J.L. (2004). Application of fuzzy optimization to diet problems in Argentienan farms. European Journal of Operational Research. 158: 218 - 228.

12. Chang \& Sullivan, Quantitative System for Business, Prentice -Hall, 19(88).

13. Itoh, T., Ishii, H. and Nanseki, T. (2003). A model of crop planning under uncertainty in agricultural management. International Journal of Production Economics., 81-82: 555-558

14. Luenberger, David.G. (1984). Linear and nonlinear programming. Addison- Wesley publishing company.

15. Pelta, D.A., Verdegay, L.J. and Cadenas, J.M. (2003). Introducing SACRA: A decision support system for the construction of cattle diets. in: X.Yu, J. kacprzyk, C., Carlsson (Eds.). Applied Decision Support with Soft Computing. Studies in Fuzziness and Soft Computing Series. Springer-Verlag. 391-401. 
D. Darvishi SalooKolayi, A. Teimouri Yansari, S. h. Nasseri/ TJMCS Vol .2 No.3 (2011) 459-468

16. Shoacheng, T. (1994). Interval number and fuzzy number linear programming. Fuzzy Sets and Systems. 66: 301- 306.

17. Zimmermann, H.J. (1991). Fuzzy Sets Theory-and its Application. Boston. Kluwer Academic Publishers. 